\title{
Synthesis of poly (lactic acid) and production of scaffolds by electrospinning
}

\begin{abstract}
In this research, the synthesis of L-lactide (L-Lc), the cyclic dimer of poly (L-lactic acid) (PLLA) with a $55.20 \%$ yield and its polymerization to PLLA with different molecular weights is reported. The product was used to produce fibrous scaffolds by electrospinning using variations in concentration, distance, flow and voltage. A high-resolution stereoscope was employed to find fiber diameter (500 y $1000 \mu \mathrm{m})$; PLLA with $295,000 \mathrm{~g} / \mathrm{mol}$ molecular weight (viscometry) was obtained after 96hours of reaction and yielded the best results in the electrospinning process. These scaffolds were evaluated in vitro for cell growth and cytotoxicity with human skin fibroblasts. None of the samples were cytotoxic above the permitted threshold of $50 \%$. This study provides an important increase in performance for the synthesis of poly (L-lactic acid) (PLLA) and further development in the manufacturing of scaffolds which have multiple uses.
\end{abstract}

Volume 4 Issue 6 - 2016

\author{
José Peñaranda-Armbrecht,' César Agudelo, ${ }^{2}$ \\ Fabio Zuluaga,' Carlos Valencia ${ }^{3}$ \\ 'Department of Chemistry, University of the Valley, Colombia \\ 2Department of Chemistry, University of Quindío, Colombia \\ ${ }^{3}$ Faculty of Health, Universidad del Valle, Colombia
}

\section{Correspondence: Fabio Zuluaga, Department of Chemistry, University of the Valley, Cali, Colombia,}

Email hector.zuluaga@correounivalle.edu.co

Received: November 02, 2016 | Published: December 29 2016

Keywords: Poly (L-lactic acid); L-Lactide; Fibrous scaffolds; Cytotoxicity

Abbreviations: ROP, ring opening polymerization; LA, lactic acid; DSC, differential scanning calorimetry; ECM, extracellular matrix; DMEM, modify medium eagle's dulbeco; FBS, fetal bovine serum; TGA, thermo gravimetric analysis

\section{Introduction}

The possible depletion of non-renewable raw materials and the overall increase in pollution has promoted the search for renewable sources for the production of polymers, as well as the synthesis of biodegradable polymers. ${ }^{1,2}$ Aliphatic polyesters have emerged for short and medium term applications such as sutures, films, dental materials, bags, containers for beverages and disposable materials, due to their biocompatibility and biodegradability. ${ }^{3}$ Among these, polylactic acid, PLA, has been the most studied, for several reasons: it comes from a natural source, is biodegradable and its degradation products are absorbed by the body. ${ }^{4}$ It has also been suitable for creating devices such as porous blocks, films and screws. These bioabsorbable devices have been widely used for orthopedic purposes and they also possess great advantages compared with titanium implants or other metal implants because they do not erode the bone when implanted. Additionally, they do not require an extra surgery for removal, which reduces medical costs and allows the gradual recovery of tissue as the material is degraded. Recent advances include fabrication of stents subjected to surface treatments such as pglation to control protein deposition. ${ }^{5}$ Most of the applications require the production of high molecular weight PLA which can be achieved using either high boiling solvents or depolymerization of oligomers to obtain the dimer called lactide, followed by Ring Opening Polymerization (ROP). This process has been studied with regard to the influence of many parameters such as temperature, pressure, percentage and nature of the catalyst on the molecular weight of the polymer. ${ }^{6}$ Several methods have been designed for the production of scaffolds, such as membranes or porous blocks, by solvent evaporation, lyophilization, particulate leaching, ${ }^{7-9}$ foams by injection and subsequent leaching of carbon dioxide at high pressure, ${ }^{10}$ porous fabrics by electrospinning, ${ }^{11,12}$ phase separation,,${ }^{7-9,13}$ additive manufacturing, ${ }^{14}$ laser sintering, ${ }^{14,15}$ and 3D printing. ${ }^{713-16}$ Electrospinning is a technique patented in 1934, by
Formhals ${ }^{17}$ where a polymer solution is pushed through a needle with the aid of an electric field to produce fibers with a diameter ranging from nanometers to micrometers.

This article describes the synthesis of L-lactide (L-Lc), for subsequent ring opening polymerization (ROP) to PLLA with different molecular weights and electrospinning tests to obtain fibrous scaffolds for in vitro cell growth.

\section{Experimental procedure}

\section{Synthesis of low molecular weight PLA (Oligomers)}

$40 \mathrm{~mL}$ of L-(+)-lactic acid (LA) (88 to $92 \%$, Scharlau) were placed in a dry $200 \mathrm{~mL}$ round bottom flask immersed in a sand bath with constant stirring. Starting at $70^{\circ} \mathrm{C}$, and $700 \mathrm{mbar}$, temperature and pressure variations were performed every five minutes, continuing with $90^{\circ} \mathrm{C}, 400 \mathrm{mbar}, 100^{\circ} \mathrm{C}, 300 \mathrm{mbar}$, and from 110 to $150^{\circ} \mathrm{C}, 100$ mbar. After reaching $150^{\circ} \mathrm{C}, 100 \mathrm{mbar}$, the process continued until complete water removal to yield $20 \mathrm{~g}$ of the PLLA oligomer (450$1000 \mathrm{~g} / \mathrm{mol}$, density $0.825 \mathrm{~g} / \mathrm{mL}$ ) following procedures previously established in our laboratory. ${ }^{18}$

\section{Crude Lc synthesis}

The oligomer was distilled at $250^{\circ} \mathrm{C}$ to $260^{\circ} \mathrm{C}$, adding $1.5 \% \mathrm{SnCl}_{2}$. $2 \mathrm{H}_{2} \mathrm{O}$ (Riedel - de Haën ), collecting the crude Lc in a $200 \mathrm{~mL}$ round bottom flask, dipped in an ice bath, and connected to a condenser with circulating water at $4{ }^{\circ} \mathrm{C}$. This procedure supplied $18.74 \mathrm{~g}$ of crude Lc, with a yield of $55.20 \%$. After recrystallization with ethyl acetate in a $1: 2$ weight ratio with respect to crude $\mathrm{Lc}, 15.45 \mathrm{~g}$ ( $46.50 \%$ yield) were produced.

\section{Synthesis of high molecular weight PLA through ROP}

$2 \mathrm{~g}$ of L-Lc, $13.84 \mu \mathrm{L}$ of $\mathrm{Sn}(\mathrm{Oct}) 2$ (Alfa Aesar), and $220.04 \mathrm{~mL}$ of 1-octanol (Merck) were weighed in a two-necked $100 \mathrm{~mL}$ flask under argon atmosphere in dry bag, under constant stirring at 120rpm. Subsequently, the reaction flask, under argon atmosphere, was introduced into an oil bath and heated to 140 to $145^{\circ} \mathrm{C}$. These reaction 
conditions were maintained for 24, 48, 72 and 96hours respectively, while the obtained PLLA acquired a solid consistency.

\section{Purification of high molecular weight PLA}

The above process was repeated to obtain $10.0 \mathrm{~g}$ of PLA, which was dissolved in the least amount of chloroform (Merck), with stirring at room temperature. Then, twice the volume of methanol (Merck) was added to form a milky suspension that, eventually, precipitated. This white solid was filtered in vacuum Buchner funnel to give $9.4 \mathrm{~g}$ (mp: 92 and $94^{\circ} \mathrm{C}$ ) and finally stored in a dessicator.

\section{Spectroscopic properties and characterization}

Thermal analysis: The L-Lc and PLLA were analyzed by differential scanning calorimetry (DSC) and thermogravimetric (TGA) in a TAmodulated SDTQ600 equipment at a heating rate of $10^{\circ} \mathrm{C} / \mathrm{min}$ under nitrogen atmosphere with a flow rate $100 \mathrm{~mL} / \mathrm{min}$ from $35^{\circ} \mathrm{C}$ to $350^{\circ} \mathrm{C}$, using samples weighing approximately $10 \mathrm{mg}$.

Molecular weight determination by capillary viscometry: PLLA molecular weights were determined using a 1C E-999 Ubelholde viscometer (NOOC-200), chloroform $\left(\mathrm{CHCl}_{3}\right)$ as solvent and solutions with concentrations of PLLA 0.02, 0.01, 0.007, 0.005, 0.003, 0.001g/ $\mathrm{cm}^{3}$, in a thermostatic bath at $25^{\circ} \mathrm{C}$. Elution times were measured by triplicate for each concentration and the relative viscosity calculated as 1.02793 . The specific viscosity was obtained by extrapolating to zero in the plot $\eta \mathrm{sp} / \mathrm{C}$ vs. the square root of the concentration. ${ }^{19}$ The molecular weight was obtained by the Mark-Houwink-Sakurada equation (1)

$$
[\eta]=\kappa M V^{\alpha}
$$

Where: $\kappa$ and $\alpha$ are constants characteristic of each polymer and $[\eta]$ is the intrinsic viscosity. $\kappa$ is $6,67 \times 10^{3}$ and $\alpha=0,67^{20}$

\section{Electrospinning of PLLA obtained through ROP}

The parameters to obtain the fibers were: voltage $20 \mathrm{kV}$, distance $14 \mathrm{~cm}$; flow rate of $8 \mathrm{~mL} / \mathrm{min}$. A $40 \%$ solution of PLLA $(295,000 \mathrm{~g} /$ mol) in $\mathrm{CHCl}_{3}$ was prepared and placed in a $5 \mathrm{~mL}$ syringe attached to a hose, the voltage source $(20 \mathrm{kV})$ was connected with a flow rate of $8 \mathrm{~mL} / \mathrm{min}$. The distance between the needle and the foil was $14 \mathrm{~cm}$. The fibers were collected on aluminum boxes $8 \mathrm{~cm}$ long by $5 \mathrm{~cm}$ wide and $3 \mathrm{~cm}$ thick

\section{Cellular growth}

Preparation of PLLA samples for cell growth: The preparation of PLLA samples for cell growth requires most aseptic conditions possible. The laboratory bench was cleaned with $70 \%$ ethanol. 45 vials for samples were dried. For the preparation of these scaffolds, a drill was used, so the dimensions of the scaffolds were the same. The scaffolds for cell growth were cut:

\footnotetext{
a. 3 Fibrous scaffolds of PLLA $96 \mathrm{~h}$ pure

b. 3 Fibrous scaffolds $90 \%$ PLLA $96 \mathrm{~h}$ pure and $10 \%$ of commercial PLLA.

c. 3 Fibrous scaffolds $90 \%$ PLLA $72 \mathrm{~h}$ pure and $10 \%$ of commercial PLLA.

d. 3 Fibrous scaffolds $80 \%$ PLLA $48 \mathrm{~h}$ pure and $20 \%$ of commercial PLLA.

e. 3 Fibrous scaffolds of commercial PLLA.
}

These fibrous PLLA scaffolds were used in triplicate for fibroblasts growth, which acts as an extracellular matrix (ECM) where cells may adhere and grow, thus enhancing the development of new tissue, transportation of nutrients and removal of unwanted materials. ${ }^{21}$

\section{Cytotoxicity test of fibrous scaffolds}

An in vitro cytotoxicity test was performed with the LDH Roche ${ }^{22}$ kit. This test is a colorimetric test used to quantify cell lysis and it is based on the LDH measure of the activity released from the cytosol of lysed cells in the supernatant. L929 cell line (ATCC CCL1, NCTC clone 929) is a human skin fibroblast line subcloned from the line $\mathrm{L}^{23}$

\section{Preparation of working solutions}

A $1 \mathrm{~mL}$ of the catalyst aqueous solution was added and stirred for 10 minutes. This solution can be kept for weeks at $2-8^{\circ} \mathrm{C}$. The dye solution is stored at $2-8^{\circ} \mathrm{C}$. For the 100 trials, $100 \mu \mathrm{L}$ of the catalyst with $11.25 \mathrm{~mL}$ of dye solution was mixed.

\section{Cellular culture}

The number of defrosted cells was determined by the tripan blue method and they were seeded in a concentration of 150.000 cells per well in a 24 well (FALCON) plate with a growing medium (Modify medium Eagle's Dulbeco (DMEM)), supplemented with $10 \%$ fetal bovine serum (FBS) (GIBCO BDRL), 2mM L-glutamine buffered saline (PBS). The cell plate was incubated for $48 \mathrm{~h}$ with $\mathrm{CO}_{2}$ at $37^{\circ} \mathrm{C}$, until a growth of $100 \% .{ }^{23}$ After incubation time and further verification of cell confluence, fibrous PLLA scaffolds were added as the final product. All triplicate samples were mounted as shown in Figure 1. The 24-well plate containing the samples described above and cells were incubated at $37^{\circ} \mathrm{C}$ in $\mathrm{CO}_{2}$ incubator for 24 hours.

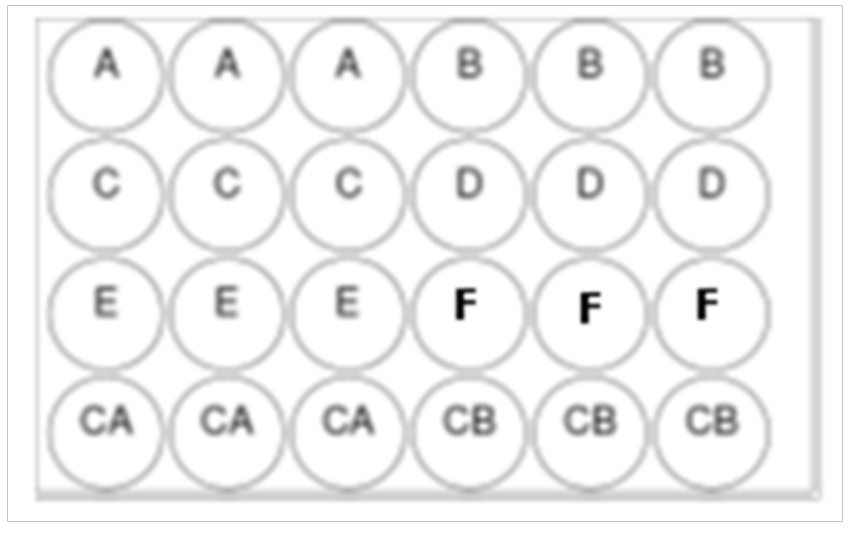

Figure I Schematic representation of a 24-well plate. Note that there are three wells on each plate with each of the treatments A, B, C, D, E and F. In addition, arranged in each plate, there were two controls: (I) a high control $(C A)$ and (2) an under control (CB), each in triplicate (three wells).

The arrangement of the materials to be analyzed in 24-well plate was:

A: Cell culture medium (white).

B: Cells+pure PLLA 96h.

C: Cells+commercial PLLAI.

D: Cells+pure $80 \%$ PLLA 48h and commercial 20\% PLLA.

E: Cells+pure $90 \%$ PLLA $72 \mathrm{~h}$ and commercial 10\% PLLAl.

F: Cells+pure 90\% PLLA 96h and commercial I0\% PLLA.

CA: Cells+culture medium+triton solution.

CB: Cells+culture medium. 


\section{Cytotoxicity test with LDH Kit $®$ ROCHE}

After the incubation time, $100 \mu \mathrm{L}$ of supernatant were transferred from each well of the first plate to the corresponding wells in a 96 well plate, $100 \mu \mathrm{L}$ of $\mathrm{LDH}$ reagent were added and the incubated plate at room temperature was protected from light for 30minutes. After this time the optical density was determined using a micro-plate reader for ELISA, STAT-FAX 2100, at a wavelength of $456 \mathrm{~nm}$ with a reference filter $492 \mathrm{~nm}$. In order to determine cytotoxicity, the LDH<smiles>C[C@H](O)C(=O)O</smiles>

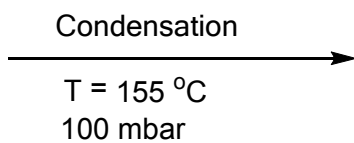

$\mathrm{L}(+) \quad$ Lactic acid

Figure 2 Oligomerization reaction of $\mathrm{AL}$.

The molecular weight of the formed oligomer can be controlled using different catalysts, functionalizing agents or by changing the polymerization conditions. ${ }^{25}$ Direct poly-condensation of LA in situ is not applied in an industrial scale because of the competition between technique was performed with measurements at $72 \mathrm{~h}$ post incubation with materials and incubation for 30 minutes with the LDH reagent with the Stat Fax-2100 at a wavelength of $456 \mathrm{~nm}$ with a reference wavelength of $490 \mathrm{~nm}$.

\section{Results and discussion}

Commercial LA (88-92\%) consists of dimers, trimers and Lc. ${ }^{24}$ Upon heating a PLA oligomer is formed as shown in Figure 2.<smiles>C[C@H](O)C(=O)O[C@@H](C)C(=O)O[C@H](C)C(=O)O[Mg]</smiles>

the formation of Lc and simultaneous degradation that occurs in the reaction. ${ }^{26,27}$ The second stage is the de-polymerization of the oligomer to give Lc, as illustrated in Figure 3.

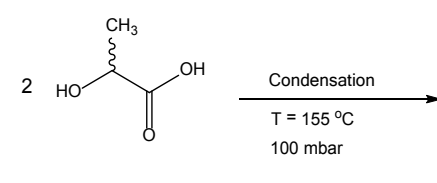<smiles>CCC(=O)O[C@@H](C)C(=O)O[C@@H](C)C(=O)O</smiles>

Low Molecular Weight prepolymer
\[ \mathrm{M}=450-1000 \]

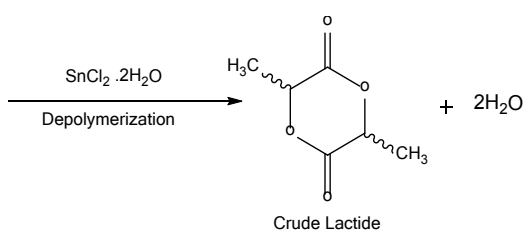

Figure 3 De-polymerization reaction to form crude Lc.

Crude Lc contains impurities such as water, LA, a mixture of oligomers such as L, D and D L Lc and L-Lc, the last of which is in greater proportion. Therefore, it was necessary to recrystallize this mixture. The L-Lc specific rotation (toluene) was measured $[\alpha]_{D}=-$ $285.3^{\circ} \mathrm{C}$ after 10 repetitions, with a standard deviation of 9,366 , very close to that reported by McDonald ${ }^{28}$ and Aldrich: $:^{29}[\alpha]_{\mathrm{D}}=-285^{\circ} \mathrm{C}$.

\section{Characterization of reactants and products}

Infrared spectra of materials used in this study are consistent with those reported in the literature and in our own laboratory. ${ }^{30-34}$

\section{Recrystallization of Lc}

The crude Lc and water react together at a relatively low temperature dissolving some impurities such as meso Lc. Additionally, the D and L-Lc are hydrolyzed and separated from de original solution. Thus meso-Lc is easily removed by recrystallization allowing the pure Lc formation, starting material for high molecular weight PLLA. ${ }^{35}$

\section{Viscometry}

The specific viscosity $[\eta]$ was 30,488 employed in the calculation of the molecular weight using the Mark Houwink Sakurada equation.

$$
M w=\left(\frac{[\eta]}{k}\right)^{1 / a}=\left(\frac{30,488}{6,67 \times 10^{-3}}\right)^{1 / 0,67}=2.95 \times 10^{5} \mathrm{~g} / \mathrm{mol}
$$

This molecular weight is adequate for electrospinning of the samples.

\section{Thermal analysis of the synthesized compounds}

L-lactide: The melting temperature $\left(\mathrm{T}_{\mathrm{m}}\right)$ was $95.65^{\circ} \mathrm{C}$ and the decomposition temperature $\left(\mathrm{T}_{\mathrm{d}}\right) 195.12^{\circ} \mathrm{C}$. The values found in the literature differ greatly for example Fuentes et al. ${ }^{36}$ reported a melting temperature of $119.8^{\circ} \mathrm{C}$, a difference that could be due to the contribution of DL-racemic mixture. PLLA: The $\mathrm{T}_{g}$ observed was $70.54^{\circ} \mathrm{C}, \mathrm{T}_{\mathrm{m}} 143.6^{\circ} \mathrm{C}$ and the $\mathrm{T}_{\mathrm{d}}$ is $306.43^{\circ} \mathrm{C}$. The thermal characteristics of PLLA are important for manufacturing fibrous scaffolds by electrospinning. A relatively high $\mathrm{T}_{g}$ with respect to the reported $70.54^{\circ} \mathrm{C}$ shows that the synthesized PLLA is high molecular weight. It should be noted that $\mathrm{T}_{\mathrm{g}}$ and $\mathrm{T}_{\mathrm{m}}$ increase as the molecular weight increases and are strongly influenced by the degree of crystallinity of PLLA. A relatively high $\mathrm{T}_{\mathrm{g}}$ of $68^{\circ} \mathrm{C}$ for a highly crystalline PLLA was reported by Gupta. ${ }^{26} \mathrm{~T}^{\mathrm{g}} \mathrm{T} \mathrm{T}_{\mathrm{g}}$ for $96 \mathrm{~h}$ PLLA obtained by us is very close to this temperature, indicating that the obtained PLLA was highly crystalline. It was also found that the PLLA with a $\mathrm{T}_{g}$ of $70.2^{\circ} \mathrm{C}$ has a $49 \%$ degree of crystallinity, which indicates a satisfactory percentage of crystallinity for our $96 \mathrm{~h}$ PLLA, that would make it suitable for electrospinning. ${ }^{37}$

Thermogravimetric Analysis (TGA) of L-Lc: This analysis was performed on the same machine and the same parameters of the experimental part and results session. It is concluded that L-Lc starts 
its decomposition at a temperature of $108.5^{\circ} \mathrm{C}$ with a weight loss of $6.7 \%$ and reach a high degree of decomposition at $195,1{ }^{\circ} \mathrm{C}$ with a weight loss of $95 \%$.

TGA analysis of PLA 96h: The PLA started decomposition at a temperature of $250.33^{\circ} \mathrm{C}$ with a rate of $95.03 \%$ weight and achieved a high degree of decomposition at $318.3^{\circ} \mathrm{C}$ with the weight percentage of $1.81 \%$.

\section{Electrospinning}

The parameters used are similar to those reported by Zong et al. ${ }^{38} \mathrm{~A}$ $40 \%$ (W/V) of a 90:10 mixture of PLA molecular weight $295,000 \mathrm{~g} / \mathrm{mol}$ and commercial PLA was prepared and subjected to electrospinning and the fibers were collected on aluminum rectangular boxes. These samples were used for cell growth. ${ }^{39}$

\section{Cytotoxicity tests}

To calculate cytotoxicity is necessary to check the three controls in this experiment: the first control is the cell culture medium, which provides information on the activity of LDH. The absorbance value obtained in this control should be subtracted from the values of the other controls. The second control is labeled as "under control", which provides information on the activity released from untreated normal cells. The third control is labeled as the "high control", which provides information on the maximum activity of the LDH enzyme released

Finally the equation (2) is used to determine the percentage of cytotoxicity of each of the compounds tested.

$$
\text { Cytotoxicity }(\%)=\frac{\text { Sample Lecture }-C B}{C A-C B} \times 100
$$

The percentage cytotoxicity is calculated by applying equation (2) to all samples. Table 1 shows the results of cytotoxicity of PLLA.

Table I Results of the cytotoxicity test of the PLLA samples

\begin{tabular}{ll}
\hline Muestras & Cytotoxicity (\%) \\
\hline PLLA 96h & $49,34 \pm 0.01$ \\
PLLA comercial & $23,00 \pm 0.01$ \\
80\% PLLA 48h pure y 20\% PLLA commercial & $42,76 \pm 0.01$ \\
$90 \%$ PLLA 72h pure y 10\% PLLA commercial & $32,12 \pm 0.01$ \\
& \\
$90 \%$ PLLA 96h pure y $10 \%$ PLLA commercial & $42,93 \pm 0.01$
\end{tabular}

According to Table 1, the synthesized PLLA have the greatest value of all. The commercial PLLA has the lowest value. Nevertheless, Lozano $(2013)^{40}$ argues that the fibrous blocks made of PLLA by less than $50 \%$ are not considered cytotoxic. Therefore, all PLLA synthesized in this study did not exhibit cytotoxicity and are considered useful in applications with living cells. The next step is to carry our histological tests in vivo.

\section{Conclusion}

We found that mixtures of synthesized PLA $(295,000 \mathrm{~g} / \mathrm{mol})$ with commercial PLA, 90/10 by weight were successfully processed by electrospinning obtaining fibrous matrices that gave favorable results in cytotoxicity tests with human skin fibroblasts.

\section{Acknowledgements}

The authors thank the Center of Excellence New Materials (CENM) and the Universidad Del Valle for financial support to successfully complete this investigation.

\section{Conflict of onterest}

The author declares no conflict of interest.

\section{References}

1. Correa LS, Zuluaga F, Valencia C, et al. Elaboración de Andamios Porosos Osteoinductivos de Poli (Ácido L-Láctico)/Quitosano para la Regeneración de Tejido Óseo. Revista Colombiana de Materiales. 2015;6:34-53.

2. Imre B, Pukanszky B. From natural resources to functional polymeric biomaterials. European Polymer Journal. 2015;60:481-487.

3. Tian H, Tang Z, Zhuang X, et al. Biodegradable synthetic polymers: preparation, functionalization and medical applications. Progress in Polymer Science. 2012;37(2):237-280.

4. Lasprilla AJ, Martínez G, Lunellia BH, et al. Poly-lactic synthesis for application in biomedical devices-A Review. Biotechnology Advances. 2012;30(1):321-322.

5. Vert M. After soft tissues, bone, drug delivery and packaging, PLA aims at blood. European Polymer Journal. 2015;68:516-525.

6. Yoo DK, Kim D, Lee DS. Synthesis of Lactide from Oligomeric PLA: Effects of Temperature, Pressure, and Catalyst. Macromolecular Research. 2006;14(5):510-516.

7. Singh M, Kasper F Kurtis, Mikos AG. Tissue Engineering Scaffolds. 3rd ed. Biomaterials Science. 2013. p. 1138-1159.

8. Okamoto M, John B. Synthetic biopolymer nanocomposites for tissue engineering scaffolds. Progress in Polymer Science. 2013;38(10):14871503.

9. Nam YS, Park TG. Porous biodegradable polymeric scaffolds prepared by thermally induced phase separation. J Biomed Mater Res. 1999;47(1):8-17.

10. Harris LD, Kim BS, David J. Open pore biodegradable matrices formed with gas foaming. Journal of Biomedical Materials Research. 1998;42(3):396-402.

11. Kai D, Liow SS, Loh XJ. Biodegradable polymers for electrospinning: towards biomedical applications. Mater Sci Eng C Mater Biol Appl. 2014;45:659-670.

12. Rogina A. Electrospinning process: versatile preparation method for biodegradable and natural polymers and biocomposite systems applied in tissue engineering and drug delivery. Applied Surface Science. 2014;296:221-230.

13. Kramschuster A, Turng, L-S. Fabrication of Tissue Engineering Scaffolds, Handbook of Biopolymers and Biodegradable Plastics: Properties. Processing and Applications. 2012:427.

14. Yeong WY, Chua CK, Leong KF, et al. Rapid prototyping in tissue engineering: challenges and potential. Trends Biotechnol. 2004;22(12):643-652.

15. Hutmacher DW, Sittinger M, Risbud MV. Scaffold-based tissue engineering: rationale for computer-aided design and solid free-form fabrication systems. Trends Biotechnol. 2004;22(7):354-362.

16. Ang TH, Sultana FSA, Hutmacher DW, et al. Fabrication of 3D chitosanhydroxyapatite scaffolds using a robotic dispensing system. Materials Science and Engineering: C. 2002;20(1):35-42. 
17. Ramakrishna S. An introduction to electro spinning and nanofibers. India: World Scientific; 2005. p. 1-48.

18. Betancourt J, Correa JP. Síntesis y Caracterización de ácido poli ( $L-$ Láctico) y su aplicación como dispositivo de fijación ósea (pregrado). Colombia: Universidad del Valle, Escuela de Ingeniería de Materiales; 2009: p. 51-75.

19. American Standard Testing Methods. Standard specifications and operating instructions for glass capillary kinematic viscometers. ASTM (D 446-12), 1995. $12 \mathrm{p}$

20. Mark JE. Polymer Data Handbook. 1st ed. USA: Oxford University Press; 1999. $629 \mathrm{p}$

21. Zong X, Kim K, Fang D, et al. Structure and process relationship of electrospun bioabsorbable nanofiber membranes. Polymer. 2002;43:4403-4412.

22. KIT ROCHE. Versión 6, kit for 2000 test store at- 15 to $-25^{\circ} \mathrm{C} .2006$.

23. Criollo WD. Ensayo Citotoxicidad in vitro de un biocompuesto. USA: Guía de Laboratorio, Universidad del Valle; 2013. p. 1-13.

24. Auras R, Harte B, Selke S. An overview of Polylactides as packaging materials. Macromol Biosci. 2004;4(9):835-864.

25. Mehta R. Modeling and simulation of poly(lactic acid) polymerization (Doctorado). India: Deemed University, Instituto de Ingeniería y Tecnología; 2007. p. 10-120.

26. Gupta AP, Kumar V. New emerging trends in synthetic biodegradable polymers-Polylactide: A critique. European Polymer Journal. 2007;43(10):4053-4074

27. Vasquez JD. Desarrollo de estructuras porosas de ácido láctico (PLA) para la regeneración ósea (Pregrado). Colombia: Universidad del Valle, Facultad de Ingeniería de Materiales; 2010. p. 17-35.

28. Mcdonald RT, Mccarthy SP, Gross R. Enzymatic degradability of poly (lactide): effects of chain stereochemistry and material crystallinity. Macromolecules. 1996;29(23):7356-7361.
29. Aldrich. Catalogue of Fine Chemicals. 2014.

30. Zuluaga HF, Insuasty B, Yates B. Análisis clásico y espectral. 1st ed. USA: Editorial Universidad del Valle; 2000. p. 77-118.

31. Garlotta D. A Literature Review of Poly (Lactic Acid). Journal of Polymers and Enviroment. 2002;9(2):63-84.

32. Zuluaga HF. Algunas Aplicaciones del Ácido Poli-L-Láctico. Revista Académica Colombiana de Ciencias. 2013;37(142):125-142.

33. Braun B, Dorgan JR, Dec SF. Infrared Spectroscopic Determination of Lactide Concentration in Polilactide: An Improved Methodology. Macromolecules. 2006;39(26):9302-9310.

34. Espartero JL, Rashkov S, Li SM, et al. NMR Analysis of Low Molecular Weight Poly (lactic acid)s. Macromolecules. 1996;29:3535-3539.

35. Sung IL, Chan Woo L, Masatoshi M. Melt polycondensation of L-lactic acid with $\mathrm{Sn}$ (II) catalysts activated by various proton acids: a direct manufacturing route to high molecular weight poly (L-lactic acid). Macrolecules. 2000;38(9):645-665.

36. Fuentes DA, Diazgranados JE, Perilla JE. Método para la Obtención de Lacturo de Alta Pureza a Partir de la Depolimerización de Poli(Ácido Láctico). Revista Colombiana de Química. 2006;35(2):115-123.

37. Tomita K, Nakajima T. Degradation of poly (L-lactic acid) by newly isolated thermophile". 2004. Polymer Degradation and Stability. Polymer Degradation and Stability. 2004;84(3):433-438.

38. Zong X, Kim K, Fang D. Structure and process relationship of electrospun bioabsorbable nanofiber membranes. Polymer. 2002;43(16):4403-4412.

39. Megelsky S, Sthephens JS, Chase DB, et al. Micro-and nanostructured surface morphology on electrospun polymer fibers, Macromolecules. 2002;35(22):8456-8466.

40. Lozano VL. Andamios de PCL-PLA obtenidos por la técnica de electrospinning para aplicaciones en regeneración ósea (pregrado). USA: Universidad del Valle; 2013. p. 18-98. 